The Israeli Journal of Aquaculture - Bamidgeh, IJA_69.2017.1385, 19 pages

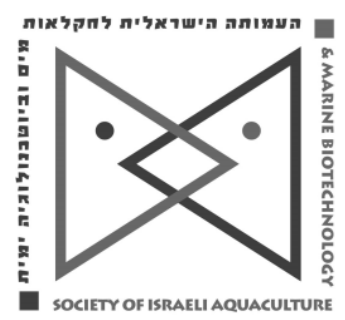

The IJA appears exclusively as a peer-reviewed on-line open-access journal at http://www.siamb.org.il. To read papers free of charge, please register online at registration form.

Sale of IJA papers is strictly forbidden.

\title{
Development of Polyculture and Integrated Multi - Trophic Aquaculture (IMTA) in Israel: A Review
}

\author{
Amir Neori ${ }^{1,2 *}$, Muki Shpigel ${ }^{1}$, Lior Guttman ${ }^{1}$, Alvaro Israel ${ }^{3}$ \\ ${ }^{1}$ National Center for Mariculture, Israel Oceanographic \& Limnological \\ Research, Eilat 8811201, Israel \\ ${ }^{2}$ Helmsley Charitable Trust Mediterranean Sea Research Center, Sedot \\ Yam, The Leon H. Charney School of Marine Sciences, University of Haifa, \\ Israel \\ 3 The National Institute of Oceanography, Israel Oceanographic \& \\ Limnological Research, Haifa 3108001, Israel, and Spanish Bank of Algae, \\ Universidad de Las Palmas de Gran Canaria, Canary Islands, Spain
}

Key words: fish; shellfish; algae; seaweed; Salicornia; oysters; clams; abalone; shrimp; carnivores; herbivores; omnivores; detritivores; nutrients

\begin{abstract}
Israeli aquaculture began in the $1920 \mathrm{~s}$, with common carp monoculture. This was followed by polyculture of carp with tilapias, grey mullet, and planktivorous carp. Scientific research on polyculture started in the 1950s and has since contributed to the global science and practice of green water aquaculture, especially with novel polyculture approaches and concepts. Today, the industry is characterized by intensive freshwater polyculture, implemented in earthen fish ponds and reservoirs. In the Mediterranean coastal plain, fresh, brackish, and marine water polyculture is carried out in semi-intensive fishponds. Polyculture in Israel is an entrepreneurial activity that combines ecological principles of Chinese polyculture with local technologies and objectives. The Biofloc approach (active suspension ponds, ASP), periphyton, and aquaponics, were developed in the $1980 \mathrm{~s}$ in response to rising public and policymakers' concerns and regulations on land use, pollution, use of chemicals, and organic manures. R\&D on marine integrated multi-trophic aquaculture (IMTA) systems began in the early 1970s at the National Center for Mariculture (NCM) in Eilat. It started with sea bream and mullet in earthen seawater ponds, whose plankton-rich water recirculated through bivalve and macroalgae biofiltration modules. An advanced form of the concept was deployed in the early 1980s and was studied in detail using nutrient budgets. Several system models with fish, bivalves, and algae, on small and pilot scales, were studied and quantified. Abalone, sea urchins, shrimp, brine shrimp, Salicornia, and periphyton, were added to the Eilat marine IMTA models, beginning in the 1990s. Upon entering the third millennium, Israeli research further examined the relationship between the sustainability and economics of IMTA in world aquaculture.
\end{abstract}

\footnotetext{
* Corresponding author. e-mail: neori@ocean.org.il; aneori@gmail.com .
} 


\section{Introduction}

The development of aquaculture in Israel has closely paralleled the general economic development of the country (Shapiro 2006). From the outset, Israeli aquaculture benefited from the organization and close relationship between government, business, research entities, and enthusiasts. Economic changes, privatization, ecological concerns, new methods, and new species have contributed to an expansion of the industry, from small-scale kibbutz (cooperative villages) operations producing one or two species, to large multimillion-dollar projects dealing with a multitude of species.

Israeli polyculture has been implemented in conventional earthen fish ponds and reservoirs. Typically, such water impoundments were stocked with a combination of common carp (Cyprinus carpio), silver carp (Hypophthalmichthys molitrix), tilapia hybrids (Oreochromis aureus $x$ O. Niloticus), and often also grey mullet (Mugil cephalus). Some farms have also added grass carp (Ctenopharyngodon idella), red drum (Sciaenops ocellatus), and a hybrid silvercarp $x$ bighead carp ( $H$. molitrix $x H$. nobilis). Over the years, additional fresh water species were tested (Golani and Mires 2000). Entrepreneurs and research stations have cooperated closely in their research with commercial Israeli farms. Israeli scientists and practitioners have shared their expertise with other countries, particularly SE Asia (Hepher and Pruginin 1981), and South America.

\section{Early Development of Israeli Polyculture}

(adapted from Shapiro 2006)

Carp culture was introduced into Israel under the British administration during the late 1920s (Simon 2009). An experimental green water carp farm was established in 1934 on the Mediterranean coast, between Acre and Haifa (Hornell 1934). Kibbutz Nir David, near the Jordan River and south of the Sea of Galilee, began farming common carp in the late 1930s. By the end of the decade, commercial carp farming had expanded throughout the region, supported by the Jewish Agency, with the help of Yugoslavian instructors and supported by University research teams [Personal information].

In the 1940s, an outbreak of a virulent phytoflagellate in brackish water ponds threatened the infant industry. Hebrew University of Jerusalem scientists soon identified it as Prymnesium parvum (Haptophyta) and developed an effective treatment, using high doses of ammonium sulphate (Shilo (Shelubsky; Shilo 1953). A fish diseases laboratory headed by S. Sarig was established in 1944 at Nir David.

By the time Israel obtained national independence in 1948, aquaculture farms covered 1400 hectares and produced over 70 percent of the fresh fish consumed in the country. In 1965 Israeli fish farm production provided over half the local consumption, which peaked at 10,100 tons but decreased slightly in the following years (Sarig 1969).

Israeli polyculture began in the early 1950s with the introduction of omnivorous blue tilapia (Oreochromis aureus) to carp ponds (Mires 1969). Tilapia thrived in the hot climate and variable water salinity levels, and complemented the carp in its nutritional requirements (Mires 1969), thereby enhancing the ecological efficiency of the production. The Ministry of Agriculture's Department of Fisheries was involved in this research from its inception. Following initial field experiments in commercial farms (Mires 1969), the Dor Aquaculture Research Station, established on the Mediterranean coast in 1955 began investigating additional fish species - exotic species that were soon included in Israeli polyculture. The phytoplanktivorous filter-feeder silver carp was introduced in 1969 to control blooms of green microalgae, thereby improving the quality of the fish flesh. Several management practices and improved supplementary feeds (aquafeeds) were developed in the Ginnosar research station (located on the shore of the sea of Galilee), and drastically raised commercial yields from 1 ton/ha to about 6 tons/ha (Sarig 1969).

Aquaculture in the Galilee, Gilboa, and Jordan Valley regions uses both freshwater and brackish water and is characterized today by dual purpose fish ponds, integrated with crop irrigation. This approach, now a few decades old, has been a significant step in the intensification of inland fish culture in Israel. On the Mediterranean coastal plain, polyculture is carried out in fresh, brackish, and marine water fish ponds (Shapiro 2006). 
In summary, Israeli polyculture is an entrepreneurial activity that, assisted by science, combines the ecological principles of Chinese polyculture with local technologies and objectives. It produces several species of fish whose complementary feeding habits maximize nutrient utilization.

\section{Israeli Research on Polyculture}

Since the middle of the $20^{\text {th }}$ century, Israeli scientists such as Hepher (Hepher 1952; 1962), have contributed greatly to the global development and scientific understanding of green water and polyculture. Their work provided significant scientific information, which filled a world information gap (Coleman and Edwards 1987). ${ }^{1}$ Yoram Avnimelech, Lev Fishelson, Balfour Hepher, Gideon Hulata, Dan Mires, Ana Milstein, Yoel Pruginin, Shmuel Sarig, Moshe Shilo, Giora Wohlfarth, and others published numerous studies on polyculture, some of which are mentioned in this review. Boaz Moav (Hinitz and Moav 1999) and Gerlad Schroeder (Schroeder 1978), also contributed significantly. Several seminal review books were published in the 1970s and 1980s (Hepher 1978; Hepher 1988; Hepher and Pruginin 1981).

Rising concerns about land use and pollution that led to stricter regulations on water disposal, and public concern about the use of chemicals and manures, raised environmental awareness in aquaculture, and led Israeli scientists to improve the sustainability of the industry (Milstein 2005), and modify the polyculture concept. In one prevalent approach, water from outdoor intensive fish ponds, raceways, and tanks was treated in sedimentation ponds and adjacent "lung" water reservoirs that recycled water back to the rearing ponds (Mires 1992; Hulata 2014). The new model consisted of several linked monoculture modules, which utilized each other's water and residues as inputs. Another development in Israeli aquaculture involved reduced intensity of the culture for better sustainability and environmental friendly purposes (Milstein 2005). Among the Israeli integrated aquaculture developments described below notably are: (a) biofloc (Avnimelech et al. 1994; Avnimelech 2006); (b) periphyton-based polyculture in freshwater (e.g., Milstein et al. 2003; reviewed in Milstein 2012), and in seawater (Levy et al. 2017); (c) aquaponics (Kolkovsky et al. 2003); and (d) integrated mariculture (IMTA, see below).

(a) Biofloc: The development of the biofloc (active suspension ponds, ASP) approach by Avnimelech and co-workers in the early 1980s (reviewed in Crab et al. 2007) used principles taken from conventional domestic wastewater treatment. When heterotrophic bacteria and algae are grown together in well-aerated and carbohydrate (e.g., cellulose) enriched water, they combine the inorganic fish-waste nitrogen $(N)$ with the carbohydrate and create protein-rich flocs. These flocs are nutritious to suspension-feeders (fish and shrimp) and reduce their food conversion ratio (FCR). An efficient microbial assimilation of waste $N$ into flocs requires a well-balanced supply of carbon $(C)$ and nitrogen $(N)$, and the maintenance of adequate light, oxygen, and temperature. In some biofloc studies, $\mathrm{N}$ recovery, by fish or shrimp doubled compared to conventional ponds (Avnimelech et al. 1994; Avnimelech 2015).

(b) Periphyton: The periphyton approach depends on attached aquatic organisms (mainly plants) that grow on submerged substrates installed in polyculture ponds (Milstein 2012). The periphyton food web adds significantly to the primary production by the suspended phytoplankton in the green water. Furthermore, the periphyton biomass is more concentrated and is therefore grazed more efficiently by fish and shrimp than diluted suspended food.

(c) Aquaponics: Israeli aquaponics has combined the culture of fish and plants (vegetables and fruit trees) in flow-through and recirculating systems (Kolkovsky et al. 2003; Kotzen and Appelbaum 2010, Appelbaum and Kotzen 2016). Commercial aquaponics with tilapia and vegetables was pioneered in the Negev Desert (Pruginin et al. 1988; Rothbard and Peretz 2002; Kolkovsky et al. 2003). Several intensive fish farms

\footnotetext{
${ }^{1}$ In alphabetical order
} 
used geothermal water in fish culture raceways (tilapia and exotic fish, both ornamental and edible), and subsequently used the effluent for crop irrigation.

(d) Integrated Mariculture Systems (IMTA): Early Israeli research and development of modern IMTA involved significant R\&D efforts founded on traditional multi-trophic culture systems of green water aquaculture and polyculture (Hepher 1985; Kolkovsky et al. 2003). The existence of scientific and practical know-how, together with a drop in fishing in the eastern Mediterranean and a freshwater shortage in the country (particularly in the arid south), promoted the modernization of aquaculture, and the initiation of mariculture in Israel in the late 1970s (Gordin 1983; Gordin et al. 1981; Motzkin et al. 1982). These concerted activities started with the establishment of the National Center for Mariculture (NCM) in Eilat, under the umbrella of Israel Oceanographic and Limnological Research (IOLR), a government-owned research entity. From the outset, NCM focused its research on the development of sustainable mariculture, and on integrated mariculture, the combined culture of two or more marine species (Gordin 1983; Gordin et al. 1981).

Trials involved earthen fishponds, in which green (or diatom-rich brown) water recirculated through bivalves and macro algae modules. Separating the organisms into separate modules was necessary, because marine culture could involve fish, bivalves, macro-algae (seaweeds), abalone, sea urchins, and shrimp, with different nutritional requirements, life histories, and potentially conflicting culture requirements and management. The integration of several monoculture modules together with water transfer between them alleviated drawbacks of polyculture (where all species share the same water body) and allowed intensification of cultures. In an integrated farm, excrement produced in one module by a fed organism pass on to other modules and are treated by extractive photosynthetic (algae or higher) plants and filter feeder organisms (Shpigel et al. 1993a; 1993b; Chopin et al. 2001; Shpigel and Neori 2007). This approach of mariculture emerged from the concept presented in Goldman et al. (1974) and Ryther et al. (1975), on the use of domestic wastewater - seawater mixtures in marine polyculture systems with microalgae, bivalve, and seaweed modules. Although efficient and relatively inexpensive, those American efforts were discontinued, partially because of doubts as to the edibility of the products. Objections are fewer for biofilter organisms cultured in fishpond effluent (e.g., Granada et al. 2015).

The interaction between fish biomass density, fish feeding, nutrient load, fish activity, water quality, light, temperature, and phytoplankton populations were first studied in earthen seawater polyculture fishponds, where the main fish was sea bream Sparus aurata, together with an assortment of secondary species, i.e., sea bass (Dicentrarchus labrax), flathead grey mullet (Mugil cephalus), rabbit fish (Siganus rivulatus, S. luridus), and green tiger prawn (Penaeus semisulcatus). Carnivorous sea bream was fed with aquafeed, and their waste supplied the nutrients for dense phytoplankton populations. This mariculture differed from freshwater polyculture by:

(1) A continuous supply of water from the sea at a flow rate of close to half the pond volume/d; and (2) Enhancement of sulphate reduction in the sediment and thereby inhibition of methane production which is in contrast to the high methane production in the sediments of freshwater ponds.

Another study evaluated the content of organic matter, silt, and parasites in the diatom-rich water, in relation to oyster performance (Hughes-Games 1977). The water exchange rate, nutrient load, and growth rate of the phytoplankton resulted in double the chlorophyll a concentration, compared to un-stocked and unfed control ponds. Oyster trays were positioned at different locations in the ponds and in separate troughs, which collected effluent from the ponds. The oysters grew well in the subtropical seawater fish ponds (salinity $41 \mathrm{~g} / \mathrm{kg}$; temperatures up to $34^{\circ} \mathrm{C}$ ). Due to the climate conditions in Eilat, oyster growth was about 1.5 greater than that in temperate waters. The stocked oysters grew from $4-92 \mathrm{~g}$ in 12 months, with high product quality and survival rate.

The dynamics of plankton and nutrients in these earthen marine 'brown water' ponds and the factors that controlled water quality were determined by several studies (Motzkin et al. 1982; Krom et al. 1985a; Krom et al. 1985b; Krom et al. 1985c; Porter et 
al. 1986; Porter et al. 1987; Blackburn et al. 1988; Krom et al. 1989a; 1989b; Erez et al. 1990; Krom 1991). These studies evaluated the processes of planktonic and benthic photosynthesis, aerobic, and anaerobic bacterial biogeochemical processes in the sediment and in the water, together with inputs, water utilization, nutrient budgets, effluent quality, oxygen dynamics, plankton dynamics, fish metabolism, and fish health. The measured fish growth was unprecedented in marine ponds.

Clean seawater flushed nearly half of the pond volume/d and the fish (mostly seabream and mullet at a ratio of 5:1, 40,000 fish/ha) incorporated $30 \%$ of feed $\mathrm{P}$ and $\mathrm{N}$ into their flesh. The excess nutrients settled or enriched the water with dissolved nutrients, which supported phytoplankton blooms. Eventually, $70-80 \%$ of the excess nutrients were discharged in the effluent. Dissolved oxygen, temperature, and dissolved inorganic N, exhibited large diurnal cycles, which were more conspicuous in summer than in winter. Studies attributed these cycles to diurnal variation in algal activity and to the metabolism of the fish. In summer, high afternoon rates of photosynthesis led to oxygen super-saturation, high $\mathrm{pH}$, and subsequent fish mortalities. Often, phytoplankton blooms 'crashed' and caused anoxia, especially before sunrise, with decreased $\mathrm{pH}$ and increased concentrations of ammonia. The dynamics of planktonic populations, nutrient levels, and rate of grazing by ciliates and flagellates, are related to these changes. Water quality is also influenced by bacterial metabolism in the sediment.

The suitability of seabream and shrimp (Penaeus semisulcatus) for growth under conditions in these ponds, as well as water quality required for adequate health and growth were defined (Kadmon 1983; Porter et al. 1986; Samocha 1986; Issar et al. 1987; Wajsbrot et al. 1989; Wajsbrot et al. 1990). These confirmed that the low-flow and intermediate-flow in earthen ponds led to progressive eutrophication (Krom et al. 1989b). Remineralisation of accumulated detritus on the bottom (Blackburn et al. 1988) led to retarded fish growth and mortality. The deterioration of water quality and the high levels of nutrients in the effluent suggest that the intensification process requires further R\&D.

\section{Integrated Mariculture (IMTA): Research and Development in the NCM campus}

\section{Original Model}

In the early 1980s, the NCM moved to its permanent campus allowing interdisciplinary and elaborate R\&D. The new campus is situated 600 meters north of the Gulf of Eilat (Aqaba), near the Israeli - Jordanian international border. The new NCM included several research departments, which together undertook complex multidisciplinary research, which was necessary for the development of modern sustainable marine aquaculture. The new campus included plastic-lined ponds of several designs, with hard or soft-bottoms, of different sizes. Aeration and stirring were incorporated in most of them. While most of the water overflowed from the surface, vortex stirring concentrated the detritus in the center of the ponds, from where the sludge was withdrawn into a sedimentation pond. Removal of the detritus reduced the organic load in the ponds and allowed further intensification (Neori et al. 1989; Krom and Neori 1989; Neori and Krom 1991; Gordin et al. 1990; Shpigel et al. 1993b). The original design of the new system involved a $50 \% / d$ seawater exchange and passage of the effluent into a common $250 \mathrm{~m}^{3}$ earthen sedimentation pond. In addition, surface water from each pond was recycled through attached oyster tanks (Shpigel et al. 1993a). Each pond was stocked with $500-700 \mathrm{~kg}$ gilthead sea bream, which were fed high-protein aquafeed daily. The annual average growth rate was near $0.5 \% / \mathrm{d}$ and the total annual production was $900 \mathrm{~kg} / \mathrm{pond}\left(9 \mathrm{~kg} / \mathrm{m}^{-3}\right.$ $/ y$ or 90 tons/ha/y). The sedimentation pond was stocked with approximately 1000 individuals of seabream and Mozambique tilapia (Oreochromis mossambicus), with a total biomass of $60-100 \mathrm{~kg}$, and its bottom was stocked with Manila clams (Tapes semidecussatus). The dissolved nutrients in the discharge from this pond to the sea were to be removed by biofiltering by a module of macroalgae ponds, but this module was never installed in full scale. 
In the three growth ponds, fish assimilated $20 \%-30 \%$ of the feed nutrient for somatic growth. About $70 \%$ of the nutrient input was stored in the particulate phase of the water column by algal blooms. The settled detritus contained on average $17 \%$ phosphorus $(\mathrm{P})$ and $10 \% \mathrm{~N}$ inputs. Intensive bacterial activity, including sulphate reduction, occurred in the detritus but not in the pond water column. Dense populations of micro-plankton developed naturally in the nutrient-rich water and dominated the particulate matter (Goldman et al. 1989; Krom and Neori 1989; Neori et al. 1989; Shpigel and Fridman 1990; Shpigel and Blaylock 1991). The phytoplankton usually consisted of a dominant alga, such as the diatoms Nitzschia sp. and Lithodesmium sp., or the green phytoflagellates Tetraselmis sp. and Euglena sp. There were also protozoa, mainly heterotrophic dinoflagellates, other flagellates, ciliates, and amoeba. A "bloom and crash" cycle of the phytoplankton community, associated with protozoan grazing of the algae, was impacted by the pond feeding regime, and occurred on a weekly or biweekly frequency, i.e., shorter than the monthly periodicity in the earthen ponds. As the pond progressed from a bloom to a crash, the fraction of the particulate phase in the total nutrient budget dropped by about $50 \%$. The concentrations of inorganic nutrients and chlorophyll a correlated inversely with each other, whereas $\mathrm{pH}$ and dissolved oxygen levels showed daily changes with magnitudes that were proportional to chlorophyll a concentration. Usually, chlorophyll a concentration in the pond ranged from medium to high (up to $0.5 \mathrm{~g} / \mathrm{m}^{-3}$ ), and the diurnal variation in water quality was dominated by fish excrement and phytoplankton metabolism. However, during times of algal "crash", this diurnal variation in water quality was determined predominantly by fish and heterotrophic plankton metabolism.

\section{IMTA of Fish with Phytoplankton and Bivalves}

Several multidisciplinary studies at NCM evaluated and quantified the performance of bivalves in the green and brown water integrated mariculture model (Gordin et al. 1990; Shpigel and Fridman 1990; Shpigel and Blaylock 1991; Shpigel et al. 1992; Shpigel et al. 1993a; Shpigel et al. 1993b; Shpigel et al. 1997; Neori and Shpigel 1999; Neori et al. 2001b; Shpigel 2005; Shpigel and Neori 2007). Oyster growth in tanks with water from the individual ponds was slow. Further studies revealed that oysters fed green and brown water from the sedimentation pond which received its water from several fishponds through a mutual sump (Shpigel and Blaylock 1991), grew more rapidly and condition indices were better than the oysters grown in tanks adjacent to the individual fishponds. It seems that the sedimentation pond provided better nutrition for oysters, possibly due to a more stable and diverse assortment of planktonic algae and benthic diatoms. These populations were completely different from those in the individual fishponds.

Manila clams also grew well at the bottom of the sedimentation pond. Compared with their natural habitat, the clams reared in relatively high summer temperatures (27$31^{\circ} \mathrm{C}$ ) and salinities ( $>41 \mathrm{~g} / \mathrm{kg}$ ), thrived and grew well indicating that Manila clams are promising for IMTA. Stocking density of the oysters was kept at $25-50 \mathrm{~kg} / \mathrm{m}^{-3}$ in tanks alongside the sedimentation pond. Green and brown water from the sedimentation pond was pumped at a rate of 1-2 tank volumes/h into one end of each oyster tank and discharged back as clearer water through a vertical standpipe at the other end. This design produced a continuous and laminar water flow, while allowing bio-deposits to aggregate at the bottom of the tanks. The filtration rates of the oysters and clams averaged $1 / 3 \mathrm{mg}$ particulate organic matter $(\mathrm{PON}) / \mathrm{g} / \mathrm{d}$. Filtration efficiency of particulate nutrient input by the bivalves was approximately $50 \%$. Higher filtration efficiencies resulted in slower growth rates of the oysters, with a lower supply of particulate nutrients compared with the bivalve biomass. Nutrient assimilation efficiency (fraction of the filtered nutrients assimilated into bivalve biomass) was between $18 \%-26 \%$. A similar fraction of the filtered particulate nutrients was regenerated as dissolved nutrients, and additional 16\%-22\% were converted into bio-deposits. Oysters and clams reached commercial sizes of $80-120 \mathrm{~g}$ and $10-16 \mathrm{~g}$ in 16 and 18 months, respectively, with average daily growth rates of $0.5 \%$ and $0.6 \%$, respectively. Both species exhibited relatively high condition indices (dry meat/dry shell $x 100$ ) throughout the year. Annual 
mortality averaged $20 \%$. Bivalves produced in the integrated mariculture system were free of human pathogens and fit for human consumption.

The ecological function of the bivalves in the system was similar to that of silver carp in freshwater polyculture, namely the uptake from the water of suspended particulate organic matter, mostly phytoplankton. Clarifying of pond water of particulate matter by the bivalves allows a significant decrease in water exchange and, proportionally a reduced discharge of nutrients to the sea. Water clarification by the bivalves also renders the water adequate for macroalgae culture. The overall yield of the three crops in relation to feed input can be two to three times higher than the yield of a modern net pen fish farm. The commercial value generated by the bivalves and the macroalgae may be significant, since at least $60 \%$ nutrient input in the fish farm could be assimilated by such crops (Shpigel et al 1993b). Anticipated average annual yields of the system (recalculated for a hypothetical 1 ha farm) are 25-35 tons of seabream, 50-100 tons of bivalves, and 30-125 tons of fresh macroalgae. Such farms require highly trained and experienced staff to balance the biological processes involved, since one must be aware of the risk stemming from the fact that all components of this system are linked and therefore depend on one another.

\section{Fish and Macroalgae: a Simple Model}

Macroalgae-based integrated farms alleviate limitations involved with green water systems. While plankton populations cloud the water, may bloom and crash, and can be washed out by excessive water exchange, macroalgae keep the water relatively transparent. Macroalgae can be easily harvested and their density maintained quite easily and independently of the water exchange rate. Experimental and theoretical studies that led to the introduction of macroalgae into the NCMs IMTA concept originated in Israel in the mid-1980s and continue to this day (Friedlander and Zelikovitch 1984; Vandermeulen and Gordin 1990; Cohen and Neori 1991; Neori et al. 1991; Gonen et al. 1994; Friedlander and Levi 1995; Israel et al. 1995; Ellner et al. 1996; Dvir et al. 1999; Neori 1991; Neori 1996; Neori 2008; Krom et al. 2001; Schuenhoff et al. 2003; Msuya and Neori 2008; Figueroa et al. 2009; Figueroa et al. 2010; Ben-Ari et al. 2014; Samocha et al. 2015; Shpigel et al. 2016).

The growth of several macroalgae species was evaluated as a function of essential environmental conditions, such as light intensity, temperature, water motion, plant density, and nutrient (N,P) enrichment with fertilizers and fishpond effluent. Species of the cosmopolitan genera Ulva and Gracilaria proved to be most suitable for these cultures. Culture of macroalgae in fishpond effluent began in the late 1980s. The approach of intensive suspension (also known as 'tumble') cultivation of macroalgae in tanks and ponds (Hanisak and Ryther 1984) was selected because it provided high yields and was easily controlled and mechanized. A vegetative clone of Ulva lactuca was stocked in bottom-aerated tanks, which were flushed with fishpond effluent. Stocking densities and nutrient supply were optimized for long-term high yields, which matched the best ever reported for any plant, $30-55 \mathrm{~g}$ dry weight $/ \mathrm{m}^{2} / \mathrm{d}$. Sedimentation pond water and effluent from bivalve tanks also supported good macroalgae growth. The growth rate of the macroalgae was linked to stocking density, water exchange rates, water nutrient content, and intensity of aeration. With proper adjustment of nutrient supply to macroalgae practically all the ammonia- $\mathrm{N}$ and a large fraction of $\mathrm{P}$ in the effluent were assimilated into harvestable Ulva biomass. With ammonia $\mathrm{N}$ fluxes (inflow rates) of $8 \mathrm{~g} / \mathrm{m}^{2} / \mathrm{d}$, assimilation efficiency ranged around $50 \%$. Night-time ammonia removal by the algae was proportional to their level of $\mathrm{N}$-starvation. The macroalgae produced were rich in protein, up to $45 \%$ in dry weight. Seabream fingerlings and oysters seemed to prefer macroalgal tank effluent over clean Red Sea water. Since 2000, new studies have developed a promising three-stage diminishing-size macroalgae biofilter system for the culture of Ulva in fishpond effluent. This system has provided a high yield of protein-rich Ulva, together with an efficient nutrient removal from the water (Neori et al. 2003; Schuenhoff et al. 2003; Msuya and Neori 2010). 
The success in the culture of macroalgae in effluent from marine fishponds prepared the ground for the development of a simple fish-macroalgae IMTA model, where relatively clear fishpond water was recirculated through macroalgae ponds (Neori 1991; Neori et al. 1993; Neori et al. 1996; Krom et al. 1995; Chopin et al. 2001; reviewed in Neori et al. 2004). The macroalgae simultaneously removed most of the ammonia excreted by the fish, converted it into a commercially valuable easily harvestable protein-rich biomass, and stabilized water quality (oxygen, $\mathrm{pH}$, turbidity and ammonia). The effluent passed a polishing stage in the form of a smaller macroalgae tank, which removed the remaining ammonia and also nitrate and nitrite. A model consisting of several tanks and a pilot consisting of $100-\mathrm{m}^{3}\left(100-\mathrm{m}^{2}\right)$ ponds were studied for several years. Both systems maintained stable and fish-safe water quality, and produced effluent quality that was superior to that of the green and brown water IMTA systems described above. The design allowed significant increases in overall water residence time (up to 5 days), i.e., a reduced exchange rate with the sea, and produced a high yield of high-protein macroalgae in addition to the fish. Farmed Ulva in its fresh, dried, and frozen forms has been gaining markets as a nutritious and sustainable human food, and as an enrichment ingredient of ornamental fish aquafeeds (e.g., Mazarrasa et al 2014). A seabream - Ulva farm of this model is expected to produce at a minimum 55 tons of fish and 385 tons fresh weight of macroalgae/ha/y, together with clean effluent. Calculations for a salmon and Gracilaria farm in Chile predict the production of 92 tons of fish and 500 tons fresh weight of Gracilaria/ha/y.

Fish with Macroalgae and Macroalgivores (Abalone and Sea Urchins)

The availability of fresh protein-rich macroalgae from IMTA led to the evaluation of a macroalgivore as a secondary animal crop in the fish-macroalgae IMTA farm (Kissil et al. 1992; Shpigel and Neori 1996; Shpigel et al. 1996a; Shpigel et al. 1996b; Shpigel et al. 1999; Neori et al. 1998; Neori et al. 2000; Neori et al. 2001a; Neori et al. 2001b; Lee et al. 2004; Nobre et al. 2010). The basic design consists of interconnected modules for the culture of fish, macroalgae, and macroalgivores (abalone and sea urchins). The macroalgivore Siganus sp. is a further option (e.g., Ben-Tuvia et al. 1973; Xu et al 2011), to be examined in the future. These modules can be arranged in different ways, according to location, market, operational, and other requirements or constraints. NCM's research provided designers with optimal dimensions, stocking densities, operation protocols, expected yields, and proximate revenue structures for several such farm models. One simple design uses macroalgae ponds that are fertilized with inorganic nutrients to feed macroalgivores in nearby tanks; the nutrient-rich effluent passes through or recirculates through the macroalgae module, where the nutrients are recovered. Thus, the macroalgivore module provides the macroalgae module with water and some nutrients, while the macroalgae module provides the macroalgivore module with both food and biofiltration. This model has been implemented with economic success in South Africa, where kelp (Eklonia) is fed, together with farm-grown Ulva, to the abalone, and fertilizers serve as an exogenous source of nutrients (Nobre et al. 2010). This IMTA design is simple, operationally compact, with low construction and operational costs. It was more profitable than a control abalone monoculture operation on the same farm.

A three-species system incorporates the culture of fed finfish, such as seabream, into the simpler macroalgae-abalone farm. In this design, as it was implemented at the Seaor Marine farm (below), seawater flowed through abalone modules and consequently drained through the aquafeed-fed fishponds into macroalgae ponds, and then discharged or recycled into the fishponds. Aquafeed supplied most of the nutrients to the Seaor farm. The different modules were scaled so that fish excrement, macroalgae nutrient uptake, production of protein-rich macroalgae biomass, and abalone macroalgae nutrition requirements were all well-proportioned. The farm initially produced fish and abalone that used the entire macroalgae production with little waste (Neori and Shpigel 2006; Nobre et al. 2010). 
Fishponds with Biofilters of Constructed Wetlands with Salicornia Spp.

Several species of the halophyte Salicornia are valuable fresh vegetable crops that thrive in harsh saline conditions, including seawater (Ventura and Sagi 2013). Salicornia (glasswort, pickle weed, marsh samphire) has been incorporated into one system with intensive fishponds (Bunting and Shpigel 2009; Ventura et al. 2011: Shpigel et al. 2013). IMTA system with a constructed wetland, such as the Salicornia wetland developed at NCM, suggests the use of soil or gravel as a substrate (Shpigel et al. 2013; Ventura et al. 2015). The valuable by-product, Salicornia shoots, has been established in growing markets of health food, nutraceutical, and beauty industries (e.g., Hortidaily.com 2015). Water treatment efficiencies and Salicornia production were studied and analysed, technical limitations have been defined, and conditions required for high biofiltration efficiency were identified (Shpigel et al 2013). The constructed wetlands are adaptable to marine operations with limited water flow and sufficient nutrient concentrations, i.e. hatcheries and land based recirculated marine fish farms.

\section{Fish and Periphyton, a Low-Cost Model}

Fish and shrimp culture with periphyton perhaps presents the cheapest model of integrated aquaculture. Periphyton is a plant-dominated community that develops on pre-fixed substrates, when they are introduced to the upper water column of a fertilized polyculture pond. Periphyton biomass is a nutritious addition to the planktonic biomass of normal polyculture ponds for feeding various fish such as carp (Azim et al. 2001 and 2002), tilapia (Milstein et al. 2005), catfish (Amisah et al. 2008) and freshwater prawn (Asaduzzaman et al. 2009). In experiments with tilapia, periphyton reduced commercial feed requirements by $40 \%$ with no deterioration in either fish yield or water quality (Milstein et al. 2008; 2009). Promising results in penaeid shrimp growth, survival, and production were also observed using periphyton in brackish water (Anand et al. 2013; Banerjee et al. 2010; Khatoon et al. 2009). Periphyton grazing by mullet, sea bream, and other fish has been observed in their natural habitat (Ferrari and Chieregato 1981) and in mariculture (Batzina et al. 2012). A recent development at NCM includes the use of periphyton as biofilter for effluent of semi-intensive mullet culture ponds (Levy et al. 2017), and as food for mullet fingerlings (unpublished).

In contrast to macroalgae biofilters, where ammonia-nitrogen uptake is favoured and where ammonia inhibits nitrate removal (Neori 1996), periphyton has also been suggested to support the simultaneous removal of ammonia and nitrate. The latter is assimilated or denitrified to $\mathrm{N}_{2}$ gas (Axler and Reuter 1996). Research on an integrated biofilter that involves Ulva sp. for ammonia removal and a post treatment unit of periphyton for nitrate removal has been established recently at NCM and has shown an effective uptake of total $\mathrm{N}$ and total $\mathrm{P}$ from effluent (unpublished).

\section{Integration of Detritivorous Fish with Seabream Cage Culture in the Red Sea}

The culture of omnivorous flathead grey mullet below fish sea cages recycled organic waste that settled and accumulated on the bottom in a Red Sea cage farm (Porter et al. 1996; Katz et al. 2002; Lupatsch et al. 2003). The mullet were contained in benthic enclosures open to the underlying sediment and fed only uneaten feed and undigested feces. The fish effectively removed organic $C, N$, and $P$ from the organically enriched sediment and grew at a rate equivalent to that of mullet reared in brackish inland water ponds. Eventual scaling up of such systems to a pilot or commercial scale operation would involve the deployment of large bottom enclosures for the mullet.

\section{A Complex Multi-Species Model}

A multi-species design can combine the integrated farming of organisms from several fish or shrimps, fed in green or brown water with plankton, filter feeders, macroalgae, macroalgivores and detritivores (Fig. 1). This design provides a selection of optional modules for each trophic level, depending on the choice of the farmers. A reduced number of trophic levels, as described earlier, can also be selected from this "basic" design. The selection of modules depends on factors such as economics, the size of the 
farm and the expertise that it can provide, as the increased flexibility requires highly skilled manpower and sophisticated management.

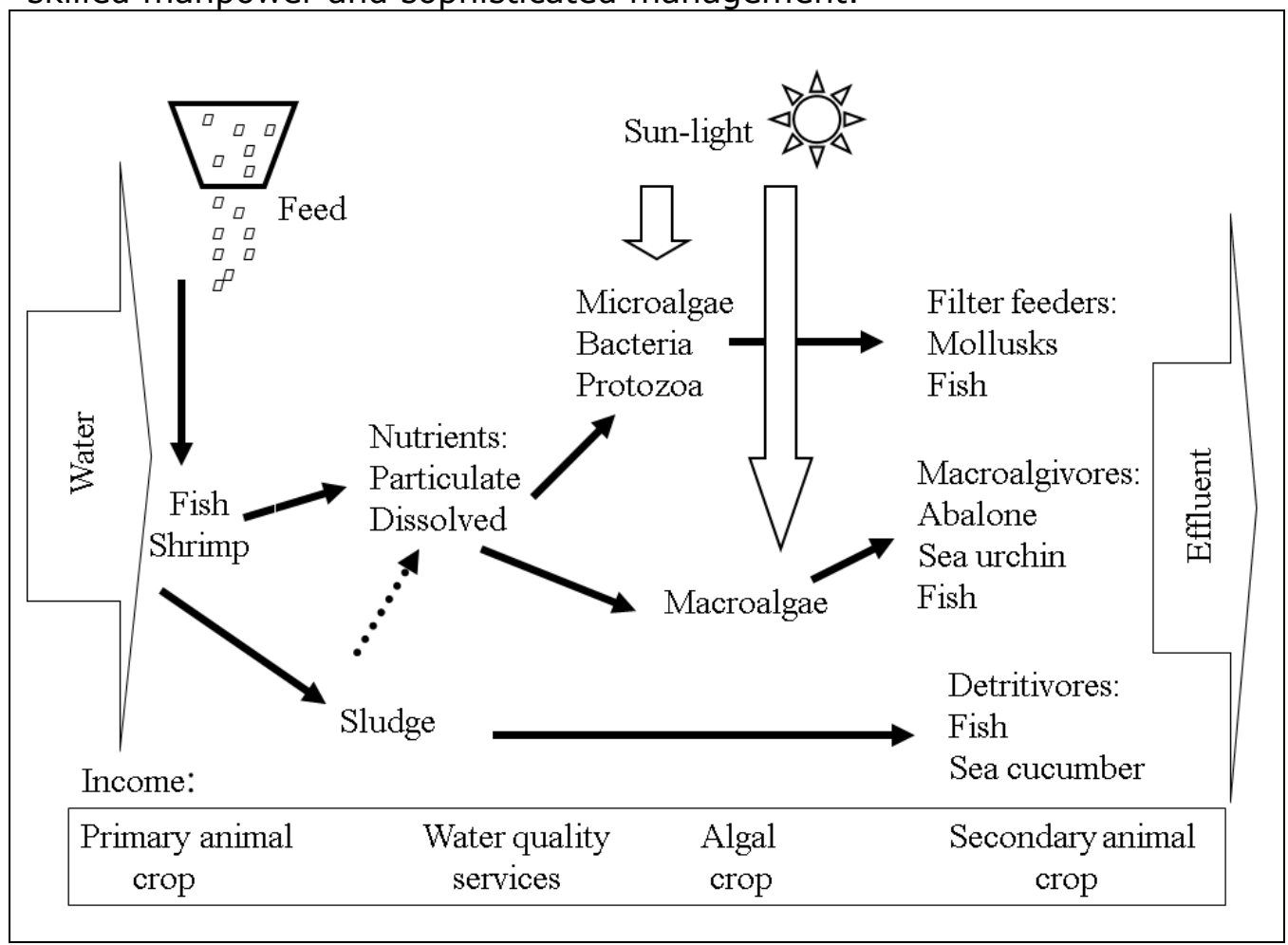

Fig. 1. A diagram of optional nutrient pathways to crops and waste in the concept of IMTA, as developed at NCM.

A multi-species design can combine the integrated farming of organisms from several trophic levels - fed fish or shrimp, greenwater / brownwater plankton, filter feeders, macroalgae, macroalgivores and detritivores (Fig. 1). This design provides the grower with a selection of modules for each trophic level, depending on the choice of the growers. A reduced number of trophic levels, as described earlier, can also be selected from this "mother" design. The selection of modules would depend on the size of the farm, the level of expertise available, as long as the farm is ecologically-balanced and profitable. The economic benefits of the complexity hinge on product diversity and farm resilience. Nutrients are supplied by fish (or shrimp) aquafeed, and biofiltration is performed by other organisms. Greenwater / brownwater effluent and benthic diatoms both feed filter-feeder clams and oysters (as well as tilapia, milkfish, etc.). The macroalgae module feeds the macroalgivores. Detritivores feed on feces and other settled organic matter.

Diversity and resilience comes at the cost of requiring larger pond areas than the three-species model for the same total production of animal products. Furthermore, this design depends on microbial processes that occur in the different ponds for its successful operation. These processes can be location-dependent, and should therefore be characterized and sufficiently understood for a successful operation. Finally, increased flexibility is achieved by increased complexity, which requires highly skilled manpower and sophisticated management.

Experimental examination of the multi-species model by the NCM was expanded in stages, until it was implemented as three, four, and even five species models in the commercial farm, SeaOr Marine, $40 \mathrm{~km}$ north of Tel Aviv (see below). The fish-planktonbivalve model was implemented semi-commercially in another farm, PGP 1994 Ltd., in Eilat. 


\section{Socio-Economics, Governance and Regulations}

A recent European effort that involves Israeli scientists has examined socio-economics, governance, and regulations issues that have a bearing on the European development of IMTA (Alexander et al. 2015; Alexander et al. 2016). Research has identified the variable levels of awareness of IMTA as an inhibition to its development in Europe. It was further proposed that waste utilization and economic benefits by IMTA farms in comparison with monoculture of fish and other organisms were helping their development, so that their overall image was positive and could promote the aquaculture industry. However, unfounded legislation and regulation of such farms, the requirement of IMTA farms for large areas, their perceived and often unfounded involvement in disease outbreaks, and food safety issues, were a hindrance. A dialogue with the different stakeholder groups and countries was suggested as the proper course to promote the development of IMTA in Europe.

\section{Commercial Enterprises}

SeaOr Marine Enterprises Ltd.

The company operated for several years on the Israeli Mediterranean coast north of Tel Aviv, where it cultured marine fish (gilthead seabream), macroalgae (Ulva and Gracilaria), and Japanese abalone (Haliotis discus hannai). It leveraged local climate and recycled fish waste products into macroalgae biomass, which was fed to the abalone. It also effectively purified the water sufficiently to enable it to be recycled to the fishponds and meet point-source effluent environmental regulations. The farm was a pilot that operated well, technically, but was too small to make a profit. New owners (Sakura Products from Nature and later Seakura - http://www.seakura.net/) have focussed on macroalgae farming, particularly Ulva and Gracilaria, for fresh and processed human food.

PGP 1994 Ltd.

The fish-plankton-bivalve model was implemented semi-commercially for several years in in Eilat. It produced microalgae-bivalve/brine shrimp that grew in effluent from marine fishponds. Surplus nutrients from fish culture supported dense microalgal populations, which fed bivalves (Crassostrea gigas and Tapes semidecussatus), that grow on the bottom of sedimentation ponds or in rearing tanks. Brine shrimp (Artemia sp.) were also produced at high rates on these microalgae. The bivalves reached commercial size in 18 months, with average daily growth rates of $0.8 \%$. Annual mortality averaged $20-30 \%$. Final stocking density was $8-10 \mathrm{~kg} / \mathrm{m}^{2}$. Brine-shrimp yields reached from $1.8-3.6 \mathrm{~kg} / \mathrm{m}^{2} / \mathrm{y}$ (Neori et al. 2001b and unpublished results).

\section{Conclusions}

Early research and development on green-water aquaculture and on polyculture in Israel and the establishment of the NCM in Eilat set the stage in human and institutional resources for rapid and significant advances. The change in emphasis from freshwater single-pond microalgae-fish systems, as in Asian polyculture, to compartmentalized (modular) marine systems of fish, microalgae, bivalves, macro-algae, and macroalgivores, was the result of a logical scientific progression.

This research demonstrated how algal and bivalve biofilters could control the major water quality problems in intensive culture of fish and shrimp, while improving effluent quality and recycling most of the waste into valuable crops of animals and algae. The IMTA concept developed in Israel is modular (Fig. 1) and flexible in the allocation of nutrient resource shares to a variety of products, based on operational and economic considerations. Seawater is pumped from the sea to ponds containing fish or shrimp fed with a pelleted diet. The effluent water from these ponds, rich in organic matter and inorganic nutrients, can be stripped of nutrients in green and brown-water ponds containing microalgae, or macro-algae. Each additional product adds to the resilience of 
the IMTA farm to internal (disease) and external (market price) fluctuations (Neori and Shpigel 2006; Nobre et al. 2010).

Commercial IMTA farms on a full scale have not developed in Israel, probably due to bureaucracy, ignorance, and entrepreneurial failure. However, the mixed culture of fish, molluscs, and macro-algae, practiced in the coastal bays of China, the culture of abalone and macro-algae in South Africa, and the culture of fish, mussels, and kelp in Canada are growing industries that provide good examples for the technical validity and economic viability of IMTA.

\section{Acknowledgments}

This review is dedicated to our late Spanish colleague and an aquaculture visionary, Guillermo García-Blairsy Reina.

The review was first prepared during a sabbatical of A Neori with BG Mitchell at the Integrative Oceanography Division, Scripps Institution of Oceanography, University of California San Diego. H Gordin, A Milstein, the Editor, and an anonymous reviewer contributed useful suggestions. AN was supported partially by Research Grant Award No. US459913R from BARD, the United States - Israel Binational Agricultural Research and Development Fund.

\section{References}

Alexander KA, Potts TP, Freeman S, Israel D, Johansen J, Kletou D, Meland M, Pecorino D, Rebourse C, Shorten M, Angel DL (2015) The implications of aquaculture policy and regulation for the development of integrated multi-trophic aquaculture in Europe. Aquaculture 443:16-23.

Alexander KA, Angel D, Freeman S, Israel D, Johansen J, Kletou D, Meland M, Pecorino D, Rebourse C, Rousou M, Shorten M, Potts T (2016) Improving sustainability of aquaculture in Europe: Stakeholder dialogues on Integrated Multi-trophic Aquaculture (IMTA). Environ Sci \& Policy 55:96-106.

Amisah S, Adjei-Boateng D, Afianu DD (2008) Effects of bamboo substrate and supplementary feed on growth and production of the African catfish, Clarias gariepinus. $J$ Appl Sci Environ Manag 12:25-28.

Anand PS, Kohli MPS, Roy SD, Sundaray JK, Kumar S, Sinha A, Pailan GH (2013) Effect of dietary supplementation of periphyton on growth performance and digestive enzyme activities in Penaeus monodon. Aquaculture 392:59-68.

Appelbaum S, Kotzen B (2016) Further investigations of aquaponics using brackish water resources of the Negev desert. Ecocycles 2:26-35.

Asaduzzaman M, Wahab MA, Verdegem MCJ, Benerjee S, Akter T, Hasan MM, Azim ME (2009) Effects of addition of tilapia Oreochromis niloticus and substrates for periphyton developments on pond ecology and production in $\mathrm{C} / \mathrm{N}$-controlled freshwater prawn Macrobrachium rosenbergii farming systems. Aquaculture 287:371-380.

Avnimelech Y (2006) Bio-filters: the need for a new comprehensive approach, Aquacult Eng 34:172-178.

Avnimelech Y (2015) Biofloc technology: fifteen years of progress. Hatchery International, October 2015 issue. Available online at: http://hatcheryinternational.com/recirc/biofloc-technology-fifteen-years-of-progress_1/. Accessed December 2016

Avnimelech Y, Kochva M, Diab S (1994) Development of controlled intensive aquaculture systems with a limited water exchange and adjusted carbon to nitrogen ratio. Isr J Aquacult Bamidgeh 46:119-131.

Axler R, Reuter J (1996) Nitrate uptake by phytoplankton and periphyton: Whole-lake enrichments and mesocosm $-{ }^{15} \mathrm{~N}$ experiments in an oligotrophic lake. Limnol. Oceanogr. 41:659-671.

Azim ME, Wahab MA, van Dam AA, Beveridge MCM, Milstein A, Verdegem MCJ (2001) Optimization of fertilization rate for maximizing periphyton production on artificial 
substrates and the implications for periphyton-based aquaculture. Aquacult Res 32:749760.

Azim M, Verdegem M, Rahman M, Wahab M, Van Dam A, Beveridge M (2002) Evaluation of polyculture of Indian major carps in periphyton-based ponds. Aquaculture 213:131-149.

Batzina A. Karakatsouli N (2012) The presence of substrate as a means of environmental enrichment in intensively reared gilthead seabream Sparus aurata: growth and behavioral effects. Aquaculture 370:54-60.

Banerjee S, Khatoon H, Shariff M, Yusoff FM (2010) Enhancement of Penaeus monodon shrimp postlarvae growth and survival without water exchange using marine Bacillus pumilus and periphytic microalgae. Fisheries Sci 76:481-487.

Ben-Ari T, Neori A, Ben-Ezra D, Shauli L, Odintsov V, Shpigel M (2014) Management of Ulva lactuca as a biofilter of mariculture effluents in IMTA system. Aquaculture 434:493- 498.

Ben-Tuvia A, Kissil GW, Popper D (1973) Experiments in rearing rabbitfish (Siganus rivulatus) in sea water. Aquaculture 1: 359-364.

Blackburn HT, Lund BA, Krom MD (1988) C-and N-mineralization in sediments of earthen marine fish ponds. Mar Ecol Prog Ser 44:221-227.

Bunting S, Shpigel M (2009) Evaluating the economic potential of horizontally integrated land-based marine aquaculture. Aquaculture 294:43-51.

Chopin T, Buschmann AH, Halling C, Troell M, Kautshy N, Neori A, Kraemer GP Zertuche-Gonzalez JA, Yarish C, Neefus C (2001) Integrating seaweeds into mariculture systems: a key towards sustainability. J Phycol 37:975-986.

Cohen I, Neori A (1991) Ulva lactuca biofilters for marine fishpond effluents. I. Ammonia uptake kinetics and nitrogen content. Bot Mar 34:475-482.

Coleman JA, Edwards P (1987) Feeding pathways and environmental constraints in waste fed aquaculture: balance and optimization. In: Moriarty DJW, Pullin RSV (eds), Detritus and microbial ecology in aquaculture, ICLARM Conf Proc vol 14, ICLARM, Manilla, Philippines, pp.240-281.

Crab R, Avnimelech Y, Defoirdt T, Bossier P, Verstraete W (2007) Nitrogen removal techniques in aquaculture for a sustainable production. Aquaculture 270:1-14.

Dvir O, van Rijn J, Neori A (1999) Nitrogen transformations and factors leading to nitrite accumulation in a hypertrophic marine fish culture system. Mar Ecol Prog Ser 181:97-106.

Ellner S, Neori A, Krom MD, Tsai K, Easterling MR (1996) Simulation model of recirculating mariculture pond with seaweed biofilter: development and experimental testing of the model. Aquaculture 143:167-184.

Erez J, Krom MD, Neubirt T (1990) Daily oxygen variations in marine fish ponds, Eilat, Israel. Aquaculture 84:289-306.

FAO (2007) The state of world fisheries and aquaculture 2006. FAO Fisheries and Aquaculture Department. Food and Agriculture Organization of the United Nations, Rome, $162 \mathrm{pp}$.

Ferrari I, Chieregato AR (1981) Feeding habits of juvenile stages of Sparus auratus L., Dicentrarchus labrax L. and Mugilidae in a brackish embayment of the Po River Delta. Aquaculture 25:243-257.

Figueroa FL, Israel A, Neori A, Martínez B, Malta EJ, Put A, Inken S, Marquardt $\mathbf{R}$, Korbee N (2009) Effect of nutrient supply and short-term stress (temperature and UV radiation) on photosynthesis and pigmentation in Ulva lactuca (Chlorophyta). Aquat Biol 7:173-183.

Figueroa FL, Israel A, Neori A, Malta EJ, Martínez B, Put A, Inken S, Marquardt R, Abdala RT, Korbee N (2010) Effect of nutrient supply on response of photosynthesis and pigmentation to short-term stress (temperature and UV radiation) in Gracilaria conferta (Rhodophyta).

Mar Pollut Bul 60:1768-1778. 
Friedlander M, Zelikovitch N (1984) Growth rates, phycocolloid yield and quality of the red seaweeds Gracilaria sp., Pterocladia capillacea, Hypnea musciformes and Hypnea cornuta in field studies in Israel. Aquaculture 40:57-66.

Friedlander M, Levy I (1995) Cultivation of Gracilaria in outdoor tanks and ponds. J Appl Phycol 7:315-324.

Golani D, Mires D (2000) Introduction of fishes to the freshwater system of Israel. The Isr J aquacult - Bamidgeh 52:47-60

Goldman JC, Tenore RK, Ryther HJ, Corwin N (1974) Inorganic nitrogen removal in a combined tertiary treatment-marine aquaculture system. I. Removal efficiencies. Water Res 8:45-54.

Goldman JC, Dennet MA, Gordin H (1989) Dynamics of herbivorous grazing by the heterotrophic dinoflagellate Oxyrrhis marina. J Plankton Res 11:391-407.

Gonen Y, Kimmel E, Friedlander M (1994) Attenuation of water velocity and incident light as a function of shape parameters in Gracilaria. J Appl Phycol 6:381-390.

Gordin H, Motzkin WL, Hughes-Games A, Porter C (1981) Seawater mariculture pond - an integrated system. In: Rosenthal $\mathrm{H}$, Oren $\mathrm{OH}$ (eds) Intensive mariculture, European Aquaculture Soc Spec Publ No 6, Bredene, Belgium, pp.1-14.

Gordin H (1983) Aquaculture: potential development. In: Brewer PG (ed), Oceanography: the present and future. Springer, NY, pp 347-361.

Gordin H, Krom MD, Neori A, Popper D, Porter C, Shpigel M (1990) Intensive integrated seawater fish ponds: fish growth and water quality. In: Rosenthal $H$, Sarig $S$ (eds), Research in modern aquaculture. European Aquaculture Soc Special Publ No 11, Bredene, Belgium, pp 45-64.

Granada L, Sousa N, Lopes S, Lemos MF (2015) Is integrated multitrophic aquaculture the solution to the sectors' major challenges? -a review. Rev Aquacult 6, 18 pages, doi: 10.1111/raq.12093.

Hanisak MD, Ryther JH (1984) Cultivation biology of Gracilaria tikvahiae in the United States. Hydrobiologia 116/117 (Dev. Hydrobiol. 22):295-298.

Hepher B (1952) The fertilization of fishponds. 1. Phosphates. Isr J Aquacult Bamidgeh 4:131-134.

Hepher B (1962) Primary production in fishponds and its application to fertilization experiments. Limnol Oceanogr 7:131-136.

Hepher B (1978) Ecological aspects of warm-water fishpond management. In: Gerking SD (ed), Ecology of fresh-water fish production. Blackwell, Oxford, pp 447-468.

Hepher B (1985) Aquaculture intensification under land and water limitations. GeoJournal 10:253-59.

Hepher B (1988) Nutrition of pond fishes. Cambridge Univ Press, New York, 404 pp.

Hepher B, Pruginin Y (1981) Commercial fish farming with special reference to fish culture in Israel. John Wiley and Sons, New York, 261 pp.

Hinitz Y, Moav B (1999) Growth performance studies in transgenic Cyprinus carpio. Aquaculture, 173(1), 285-296.

Hornell 1934, Report on the Fisheries of Palestine.

Hortidaily.com (2015) Salicornia: a great greenhouse crop for niche markets. Available at: http://www.hortidaily.com/article/20419/Salicornia-a-great-greenhouse-crop-forniche-markets. Accessed December, 2016

Hughes-Games WL (1977) Growing the Japanese oyster (Crassostrea gigas) in subtropical seawater fishponds. I. Growth rate, survival and quality index. Aquaculture 11:217-229.

Hulata G (2014) An overview of Israeli inland aquaculture. Overview of Fish Culture in Israel, Fish Breeders Association of Israel. Available at:

https://www.aquacultureinisrael.com/en/fishfarmers/israeli-aquaculture-

overview/item/14-overview-israeli-inland-aquaculture.

Israel A, Friedlander M, Neori A (1995) Biomass yield, photosynthesis and morphological expression of Ulva lactuca. Bot Mar 38:297-302.

Issar G, Seidman ER, Samocha TM (1987) Preliminary results of nursery and pond culture of Penaeus semisulcatus in Israel. Isr J Aquacult Bamidgeh 39:63-74. 
Kadmon G (1983) Ovarian physiology and breeding-related growth under aquacultural conditions in the gilthead bream, Sparus aurata. Dissertation, Tel-Aviv University, Israel, in Hebrew, $82 \mathrm{pp}$.

Katz T, Herut B, Genin A, Angel DL (2002) Grey mullets ameliorate organically enriched sediments below a fish farm in the oligotrophic Gulf of Aqaba (Red Sea). Mar Ecol Prog Ser 234:205-214.

Khatoon H, Banerjee S, Yusoff FM, Shariff M (2009) Evaluation of indigenous marine periphytic Amphora, Navicula and Cymbella grown on substrate as feed supplement in Penaeus monodon postlarval hatchery system. Aquacult Nutr 15:186-193.

Kissil G Wm, Lupatsch I, Neori A (1992) Approaches to fish feed in Israel mariculture as a result of environmental constraints. In: Kissil G Wm, Saar $L$ (eds) Proceedings of the U.S.-Israel Workshop on mariculture and the environment, IOLR-NCM, Elat, Israel, pp 74-84.

Kolkovsky S, Hulata G, Simon Y, Segev R, Koren A (2003) Integration of agriaquaculture systems - the Israeli experience, In Gooley GJ, Gavine FM (eds), Integrated agri-aquaculture systems, a resource handbook for Australian industry development, Rural Industries Research and Development Corporation, RIRDC Publication, Kingston, ACT, Australia, pp 14-23.

Kotzen B, Appelbaum S (2010) An investigation of aquaponics using brackish water resources in the Negev desert. $J$ Appl Aquacult 22:297-320.

Krom M (1991) Importance of benthic productivity in controlling the flux of dissolved inorganic nitrogen through the sediment-water interface in a hypertrophic marine ecosystem. Mar Ecol Prog Ser 78:163-172.

Krom MD, Neori A (1989) A total nutrient budget for an experimental intensive fishpond with circularly moving seawater. Aquaculture 83:345-358.

Krom MD, Porter C, Gordin H (1985a) Nutrient budget of a marine fish pond in Eilat, Israel. Aquaculture 51:65-80.

Krom MD, Porter C, Gordin H (1985b) Description of the water quality conditions in a semi-intensively cultured marine fish pond in Eilat, Israel. Aquaculture 49:141-157.

Krom MD, Porter C, Gordin H (1985c) Causes of fish mortalities in semi-intensively operated seawater ponds in Eilat, Israel. Aquaculture 49:159-177.

Krom MD, Erez J, Porter CB, Ellner S (1989a) Phytoplankton nutrient uptake dynamics in earthen marine fishponds under winter and summer conditions. Aquaculture 76:237-253.

Krom MD, Neori A, Van Rijn J (1989b) Importance of water flow rate in controlling water quality processes in marine and freshwater fish ponds. Isr J Aquacult Bamidgeh 41:23-33.

Krom MD, Ellner S, van Rijn J, Neori A (1995) Nitrogen and phosphorus cycling and transformations in a prototype "non-polluting" integrated mariculture system, Eilat, Israel. Mar Ecol Prog Ser 118:25-36.

Krom MD, Neori A, van Rijn J, Poulton SW, Davis IM (2001) Working towards environmentally friendly marine farming. Ocean Challenge 10:22-27.

Lee JJ, Rodriguez D, Zmora O, Neori A, Symons A, Shpigel M (2004) Nutrient study for the transition from earthen sedimentation ponds in integrated mariculture systems to ones lined with PVC, what needs to be done? J Appl Phycol 16:341-353.

Levy A, Milstein A, Neori A, Harpaz S, Shpigel M, Guttman L (2017) Marine periphyton biofilters in mariculture effluents: Nutrient uptake and biomass development. Aquaculture 473: 513-520. https://doi.org/10.1016/j.aquaculture.2017.03.018

Lupatsch I, Katz T, Angel DL (2003) Removal of fish farm effluents by grey mullets: a nutritional approach. Aquat Liv Res 34:1367-1377.

Mazarrasa I, Olsen YS, Mayol E, Marbà N, Duarte C M (2014) Global unbalance in seaweed production, research effort and biotechnology markets. Biotechnol Adv 32:1028-1036.

Milstein A (2005) Polyculture in aquaculture. Animal Breeding Abstracts 73 (12):15N$41 \mathrm{~N}$. 
Milstein A (2012) Periphyton-based aquaculture: underwater hard surfaces in fish ponds promote development of natural food for fish. Ind J Soc \& Nat Sci 1:93-99.

Milstein A, Azim ME, Wahab MA, Verdegem MCJ (2003) The effects of periphyton, fish and fertilizer dose on biological processes affecting water quality in earthen fish ponds. Env Biol Fish 68:247-260.

Milstein A, Peretz $\mathbf{Y}$ and Harpaz S (2008) Comparison of periphyton growth on different substrates as food for organic tilapia culture. Isr. J. Aquacult.-Bamidgeh, 60(4): 243-252.

Milstein A, Peretz Y and Harpaz S (2009) Culture of organic tilapia to market size in periphyton-based ponds with reduced feed inputs Aquacult Res 40:55-59.

Mires D (1969) Mixed culture of Tilapia with carp and gray mullet in Ein Hamifratz fish ponds. Bamidgeh 21(1): 24-32. [Scnd 21(1) 24-32]

Mires DB and Amit Y (1992) Water quality in a recycled intensive fish culture system under field conditions. The Israeli Journal of Aquaculture - Bamidgeh 44(3). [Scnd 44(3) 82-86]

Motzkin F, Cohen Y, Gordin H, Padan E (1982) Productivity relations in seawater fish ponds a comparison of stocked and unstocked ponds. Mar Ecol Prog Ser 8:203-210.

Msuya FE, Neori A (2008) Effect of water aeration and nutrient load level on biomass yield, $\mathrm{N}$ uptake and protein content of the seaweed Ulva lactuca cultured in seawater tanks. J Appl Phycol 20:1021-1031.

Msuya FE, Neori A (2010) The performance and chemical composition of spray-irrigated seaweed Ulva lactuca as a crop and as a biofilter of fishpond effluents. J Phycol 4:813817.

Neori A (1991) Use of seaweed biofilters to increase mariculture intensification and upgrade its effluents (Hebrew with an English abstract). Fisheries and Fishbreeding in Israel: Rev Fisheries in Israel 24(4): 171-179.

Neori A (1996) The form of N-supply (ammonia or nitrate) determines the performance of seaweed biofilters integrated with intensive fish culture. Isr J Aquacult.-Bamidgeh 48:19-27

Neori A (2008) Essential role of seaweed cultivation in integrated multi-trophic aquaculture farms for global expansion of mariculture: an analysis. J Appl Phycol 20:567570.

Neori A (2011) 'Green water' microalgae: The leading sector in world aquaculture. J Appl Phycol 23:143-149.

Neori A, Krom MD (1991) Nitrogen and phosphorus budgets in an intensive marine fishpond: the importance of microplankton. In: Cowey CB, Cho CY (eds), Nutritional strategies and aquaculture waste. University of Guelph, Guelph, pp 223-230.

Neori A, Shpigel M (1999) Algae treat effluents and feed invertebrates in sustainable integrated mariculture. World Aquacult 30:46-49, 51.

Neori A Shpigel M (2006) An integrated system for farming fish, seaweed and abalone. In: $C A B$ International Aquaculture Compendium, Wallingford, UK. Available only online, at:

http://www.cabi.org/ac/search/?q=An+integrated+system +for+farming +fish\%2c+seaw eed +and +abalone\&types $=19$. Accessed January 2017.

Neori A, Krom MD, Cohen I, Gordin H (1989) Water quality conditions and particulate chlorophyll a of new intensive seawater fishponds in Eilat, Israel: daily and diel variations. Aquaculture 80:63-78.

Neori A, Cohen I, Gordin H (1991) Ulva lactuca biofilters for marine fishpond effluent. II. Growth rate, yield and C:N ratio. Bot Mar 34:483-489.

Neori A, Ellner SP, Boyd CE, Krom MD (1993) The integration of seaweed biofilters with intensive fish ponds to improve water quality and recapture nutrients. In: Moshiri GA (ed), Constructed wetlands for water quality improvement, Lewis Publishers, Boca Raton, Florida, pp 603-607.

Neori A, Krom MD, Ellner SP, Boyd CE, Popper D Rabinovitch R, Davison PJ, Dvir O, Zuber D, Ucko M, Angel D, Gordin H (1996) Seaweed biofilters as regulators of water quality in integrated fish-seaweed culture units. Aquaculture 141:183-199. 
Neori A, Ragg NLC, Shpigel M (1998) The integrated culture of seaweed, abalone, fish and clams in modular intensive land-based systems: II. Performance and nitrogen partitioning within an abalone (Haliotis tuberculata) and macroalgae culture system. Aquacult Eng 17:215-239.

Neori A, Shpigel M, Ben-Ezra D (2000) Sustainable integrated system for culture of fish, seaweed and abalone. Aquaculture 186:279-291.

Neori A, Shpigel M, Scharfstein B (2001a) Land-based low-pollution integrated mariculture of fish, seaweed and herbivores: principles of development, design, operation and economics. Aquaculture Europe 2001 Book of Abstracts. Eur Aquac Soc Spec Publ 29:190-191.

Neori A, Shpigel M, Zmora O (2001b) Sustainable land-based mariculture in arid environments. In: Critchley AT (ed), Proceedings of the symposium on co-management of resources off the South-Western coast of Africa, Lüderitz, Namibia, 21-14 June 2000, Namibian Ministry of Fisheries and Marine Resources pp 124-131.

Neori A, Msuya FE, Shauli L, Schuenhoff, A, Kopel F, Shpigel M (2003) A novel three-stage seaweed (Ulva lactuca) biofilter design for integrated mariculture. J Appl Phycol 15:543-553.

Neori A, Chopin T, Troell M, Buschmann AH, Kraemer G, Halling C, Shpigel M, Yarish C (2004) Integrated aquaculture: rationale, evolution and state of the art emphasizing seaweed biofiltration in modern aquaculture. Aquaculture 231:361-391.

Nobre AM, Robertson-Andersson D, Neori A, Sankar K (2010) Ecological-economic assessment of aquaculture options: comparison between abalone monoculture and integrated multi-trophic aquaculture of abalone and seaweeds. Aquaculture 306:116126.

Porter CB, Krom MD, Gordin H (1986) The effect of water quality on the growth of Sparus aurata in marine fish ponds. Aquaculture 59:299-315

Porter CB, Krom MD, Robbins MG, Brickell L, Davidson A (1987) Ammonia excretion and total $\mathrm{N}$ budget for Gilthead Seabream (Sparus aurata) and its effects on water quality conditions. Aquaculture 66:287-297.

Porter CP, Krost P, Gordin H, Angel DL (1996) Grey Mullet (Mugil cephalus) as a forager of organically enriched sediments below marine fish farms. Isr J Aquacult.Bamidgeh, 48:47-55.

Pruginin Y, Fishelson L, Koren A (1988) Intensive tilapia farming in brackish water from an Israeli desert aquifer. In: Pullin RSV, Bhukaswan $T$, Tonguthai $K$, Maclean JL (eds), The $2^{\text {nd }}$ international symposium on tilapia in aquaculture. ICLARM Conference Proceedings Vol. 15. Dept. of Fisheries, Bangkok, Thailand and ICLARM, Manila, Philippines, pp 75-81.

Rimon A, Shilo M (1982) Factors which affect the intensification of fish breeding in Israel. I: Physical, chemical and biological characteristics of the intensive fish ponds in Israel. Isr J Aquacult.-Bamidgeh 34:87-100.

Rothbard S, Peretz Y (2002) Tilapia culture in Negev, the Israeli desert. In: Guerrero III RD, Guerrero del-Castillo MR (eds), Tilapia farming in the 21st century. Proceedings of the international forum on tilapia farming in the 21st century (Tilapia Forum 2002), Laguna, Philippines, pp 60-65,

Ryther JH, Goldman JC, Gifford CE, Huguenin E, Wing AS, Clarner JP, Williams LD, Lapointe BE (1975) Physical models of integrated waste recycling-marine polyculture systems. Aquaculture 5:163-177.

Sarig S (1969) Fisheries and fish culture in Israel. Bamidgeh 3:18-24.

Samocha TM (1986) Larval rearing techniques for penaeid shrimp emphasizing the latest results of the IOLR National Center for Mariculture, Eilat, Israel. In: Matzumoto JB (ed), Proceeding of the "Acuicultura 86" shrimp aquaculture conference and trade show of the Americas, September 26-October 5, 1986, Panama City, Panama, pp 75-88.

Samocha TM, Fricker J, Ali AM, Shpigel M, Neori A (2015) Growth and nutrient uptake of the macroalga Gracilaria tikvahiae cultured with the shrimp Litopenaeus vannamei in an Integrated Multi-Trophic Aquaculture (IMTA) system. Aquaculture 446:263-271. 
Schroeder GL (1978) Autotrophic and heterotrophic production of micro-organisms in intensely-manured fish ponds, and related fish yields. Aquaculture, 14(4), 303-325.

Schuenhoff A, Shpigel M, Lupatsch I, Ashkenazi A, Msuya FE, Neori A (2003) A semi-recirculating, integrated system for the culture of fish and seaweed. Aquaculture 221:167-181

Shapiro J (2006) Israel National aquaculture sector overview. National aquaculture sector overview fact sheets. FAO Fisheries and Aquaculture Department, Rome. http://www.fao.org/fishery/countrysector/naso_israel/en. Accessed December 2016.

Shilo (Shelubsky) M, Shilo M (1953) Conditions which determine the efficiency of ammonium sulphate in the control of Prymnesium parvum in fish breeding ponds. Appl Microbiol 1:330-333.

Shilo M, Rimon A (1982) Factors which affect the intensification of fish breeding in Israel. 2: ammonia transformations in intensive fish ponds. Isr J Aquacult.-Bamidgeh, 34:101-114.

Shpigel M (2005) Bivalves as biofilters and valuable by-products in land-based aquaculture systems. In: Dame R, Olenin S (eds), The comparative roles of suspensionfeeders in ecosystems. Springer, Dordrecht, pp 183-197.

Shpigel M, Fridman R (1990) Propagation of the Manila clam Tapes semidecussatus in the effluent of fish aquaculture ponds in Eilat, Israel. Aquaculture 90:113-122.

Shpigel M, Blaylock RA (1991) The Pacific oyster Crassostrea gigas as a biological filter for a marine fish aquaculture pond. Aquaculture 92:187-197.

Shpigel M, Neori A (1996) The integrated culture of seaweed, abalone, fish and clams in modular intensive land-based systems. I. proposed design and cost analyses. Aquacult Eng 15:313-326.

Shpigel M, Neori A (2007) Microalgae, macroalgae, and bivalves as biofilters in landbased mariculture in Israel. Chapter 24 In Bert TM (ed), Ecological and genetic implications of aquaculture activities, Springer, Dordrecht, pp 433-446.

Shpigel M, Neori A, Popper DM, Gordin H (1992) A proposed model for "clean" landbased polyculture of fish, bivalves and seaweed. In: Kissil G Wm, Saar L (eds), Proceedings of the U.S.-Israel Workshop on Mariculture and the Environment, IOLR-NCM, Elat, Israel, pp 43-55.

Shpigel M, Lee J, Soohoo, B Fridman R, Gordin H (1993a) Use of effluent water from fishponds as a food source for the Pacific oyster Crassostrea gigas Thunberg. Aquacult Fish Manage 24:529-543.

Shpigel M, Neori A, Popper DM, Gordin H (1993b) A proposed model for "environmentally clean" land-based culture of fish, bivalves and seaweeds. Aquaculture 117:115-128.

Shpigel M, Marshall A, Lupatsch I, Neori A (1996a) Acclimation and propagation of the abalone Haliotis tuberculata in a land-based system in Israel. J World Aquacult Soc 27:435-442.

Shpigel M, Neori A, Marshall A (1996b) The suitability of several introduced species of abalone (gastropoda: haliotidae) for land-based culture with pond grown seaweed in Israel. Isr J Aquacult.-Bamidgeh, 48:192-200.

Shpigel M, Gasith A, Kimmel E (1997) A bio-mechanical filter for treating fish-pond effluents. Aquaculture 152:103-117.

Shpigel M, Ragg NLC, Lupatsch I, Neori A (1999) Protein content determines the nutritional value of the seaweed Ulva lactuca $\mathrm{L}$ for the abalone Haliotis tuberculata $\mathrm{L}$. and $H$. discus hannai Ino. J Shell Res 18:1-7.

Shpigel M, Ben-Ezra D, Shauli L, Sagi M, Ventura Y, Samocha T, \& Lee JJ (2013) Constructed wetland with Salicornia as a biofilter for mariculture effluents. Aquaculture 412-413:52-63.

Shpigel M, Ben-Ari T, Shauli L, Odintsov V, Ben-Ezra D (2016) Nutrient recovery and sludge management in seabream and grey mullet co-culture in Integrated MultiTrophic Aquaculture (IMTA). Aquaculture 464:316-322.

Simon I (ed) (2009) Several articles (in Hebrew) on the early days. Fisheries and Fishbreeding in Israel 40(1), April 2009. Available at: 
http://www.fishery.moag.gov.il/NR/rdonlyres/F6AA4802-0E1C-4607-9579-

441E587ECDEE/0/Midge2009 1.pdf. Accessed December 2016.

Vandermeulen H, Gordin H (1990) Ammonium uptake using Ulva (Chlorophyta) in intensive fishpond systems: mass culture and treatment of effluent. J Appl Phycol 2:363374.

Ventura Y, Sagi M (2013) Halophyte crop cultivation: The case for Salicornia and Sarcocornia. Environ Exp Bot 92:144-153.

Ventura Y, Wuddineh WA, Myrzabayeva M, Alikulov Z, Khozin-Goldberg I, Shpigel M, Samocha TM, Sagi M (2011) Effect of seawater concentration on the productivity and nutritional value of annual Salicornia and perennial Sarcocornia halophytes as leafy vegetable crops. Sci Hortic 128:189-196.

Ventura Y, Eshel A, Pasternak D, Sagi M, Flowers TJ, Colmer TD (2015) The development of halophyte-based agriculture: past and present. Ann Bot 115:529-540.

Wajsbrot N, Krom MD, Gasith A, Samocha TM (1989) Ammonia excretion of green tiger prawn Penaeus semisulcatus as possible limit for the biomass density in shrimp ponds. Isr J Aquacult Bamidgeh 41:159-164.

Wajsbrot N, Krom MD, Samocha TM, Gasith A (1990) Effect of dissolved oxygen and the molt stage on the acute toxicity of ammonia to juvenile green tiger prawn Penaeus semisulcatus. Env Toxicol Chem 9:497-504.

Wohlfarth GW, Hulata G, Karplus I, Halevy A (1985) Polyculture of freshwater prawn Macrobrachium rosenbergii in intensively manured ponds, and the effect of stocking rate of prawns and fish on their production characteristics. Aquaculture 46:143-156.

Xu S, Zhang L, Wu Q, Liu X, Wang S, You C, Li Y (2011) Evaluation of dried seaweed Gracilaria lemaneiformis as an ingredient in diets for teleost fish Siganus canaliculatus. Aquacult Int 19:1007-1018 